\title{
The Effects of Traditional and Modern Human Resource Management Practices on Employee Performance in Business Organisations in Papua New Guinea
}

\author{
Albert C. Mellam*, Pulapa Subba Rao, Benedicta T. Mellam \\ School of Business Administration, University of Papua New Guinea, Papua New Guinea
}

Copyright $(\mathcal{C} 2015$ by authors, all rights reserved. Authors agree that this article remains permanently open access under the terms of the Creative Commons Attribution License 4.0 International License

\begin{abstract}
Employee performance is the outcome of the influence of various factors including human resource management (HRM) practices. Globalisation and information technology resulted in emergence and modern practices of HRM that are different in approach of the erstwhile HRM practices which are termed as traditional HRM Practices. Modern HRM practices are expected to produce higher employee performance scores compared to that of traditional HRM practices. Review of the existing literature on the theme of the study indicates that there are no studies covering the effects of traditional and modern HRM practices on employee performance. Therefore, the present study is expected to contribute towards plugging this gap. The purpose of this study is to ascertain the impact of modern human resource management practices on employee performance compared to that of traditional human resource management practices. Data used for this study were collected from primary sources using a questionnaire. This paper analyses the impact of traditional HRM and modern HRM practices in employee performance in business organisations in Papua New Guinea employing statistical tools like descriptive data analysis, correlation and regression analysis. SOEs mostly followed traditional HRM practices and PEs followed modern HRM practice mostly due to their organisational structures, and history of their origins. Results of the study indicate that many of the traditional HRM practices resulted in the low employee performance in SOEs whilst modern HRM practices resulted in high employee performance in PEs. It is therefore suggested that SOEs may take the advantage of high employee performance by restructuring their organisations that allow them to follow modern HRM practices.
\end{abstract}

Keywords Modern HRM Practices, Traditional HRM Practices, State Owned Enterprises, Private Enterprises, Employee Performance

Acronyms Used: HRM=Human Resource Management. SOEs $=$ State Owned Enterprises, PEs=Private Enterprises, PNG=Papua New Guinea

\section{Introduction}

Human resource management models indicate that organisational performance is based on peoples' performances, which in turn is influenced by purposes, principles, processes and practices [1]. Employee performance is the result of a number of human resource management practices and environmental factors like employee selection in order to find a best possible match between the job requirements and employee's abilities [2], training in order to bridge the gap between the employee's abilities and the changing job requirements, type of organization structure, employee compensation that includes salary, benefits and incentives [3], providing a means for employee participation, appraising and developing employee performance, and motivation through the provisions for meeting social needs and needs for recognition.

Human resource management practices vary from organisation to organisation in view of differences in impact of environmental factors, purposes, policies and procedure. These varying practices result in differences in employee performance. The recent and major shifts in environmental factors are globalisation and information technology, and these changes have had an impact on performance on employees.

Globalisation, along with information technology has brought paradigm shifts in traditional human resource management practices and thereby fundamental changes in industrial relations. The paradigm shifts from traditional human resource management practices to modern human resource management practices after 2000s include shift from giving heavy emphasis to candidates' hard skills namely technical skills, knowledge and abilities to soft skills namely, attitude, aptitude and emotional intelligence in selection process and shift from long and detailed selection process to rely on employee referrals and outsourcing and 
flexible work in order to find employee-role match; shift from providing specialised technical skills to providing multiple skills through training; providing individual-based jobs through mechanic and bureaucratic structure to ample scope for teamwork through organic structure; shift from allowing employee just to implement decisions made by senior managers to enabling employee to involve and participate in decision-making; shift from designation-based uniform compensation package to performance based differential compensation package; shift from use performance appraisal tool as a punishment measure to performance drive and development; and from motivating the employees through monetary rewards to non-monetary rewards like social and recognition needs for meeting performance standards.

\section{Need for the Study}

Modern human resource management practices are expected to produce higher employee performance scores compared to that of traditional human resource management practices.

Review of the existing literature on the theme of the study indicates that there are a few studies in other countries covering "The Way Human Resource Management (HRM) Practices Effect Employees Performance: A Case of Textile Sector" [4], "The among Private Companies in Malaysia" [5\}, "The importance of a high-performance work environment in hospitals" [6], "Subjective Performance Measures in Optimal Incentive Contracts" [7] , "Multiskilling, Technical Change and the Japanese Firm"[8], "Having your cake and eating it too? The relationship between HR and organizational performance in healthcare." [9] and "Profit Sharing and Productivity" [10] . The studies in PNG are rare to find even in the related areas. However, there are a few studies on organizational environment and human resource management in PNG [11] [12] [13] . Therefore, the present study is expected to contribute towards plugging this gap.

The purpose of this study is to find out the connections of recent human resource management practices on employee performance compared to that of traditional human resource management practices.

\section{Methodology and Results}

Data used for this study were collected from primary sources. A questionnaire with two parts was developed and administered along with interviews with the participants.
The first part of questionnaire was to gauge the extent the organizations were following traditional and modern human resource management practices with respect to selected HRM practices viz., selection, training, individual vs. teamwork, employee participation, compensation, performance appraisal and motivation. The second part of the questionnaires was to gauge the impact of human resource management practices on employee performances.

Human resource management practices covered in this study include: selection process, training and development, scope for individual based work and teamwork based on type of organization structure, employee participation in decision-making and implementation, compensation package, performance appraisal and development, and motivation in terms of social needs and esteem needs.

This is basically an empirical study about the impact of traditional and modern human resource management practices on employee performance in business organizations in Papua New Guinea.

State Owned Enterprises (SOEs) and Private Enterprises (PEs) were selected to facilitate comparison between organizations following traditional human resource management practices vis-à-vis modern human resource management practices. Five organizations from SOEs category and 5 organizations from PEs were selected purely on judgment basis, as studies of this nature had not been conducted earlier in PNG. In view of this limitation, purposive sampling technique was applied. Data were collected based on the perception of employees working in these sample organizations.

The questionnaires elicited responses from 20 employees of 10 selected based on random sampling technique from each of these sample organizations totalling to 200. However, 142 employees returned completely filled-in questionnaires. Respondent's views regarding the influence of HRM practices on employee performance using 5 degree scale; 1 being the lowest influence and 5 being the highest influence.

Descriptive data analysis, regression and correlation analysis were employed with support of MS excel data analysis tool to analyse the data and draw conclusions.

\section{Data Analysis}

Table 1 presents the scores of selected traditional and modern human resource management practices in the selected SOEs and PEs.

It is clear from Table 1 that SOEs mostly practice traditional HRM practices whereas PEs practice a mix of traditional and modern HRM practices, but they turn to modern HRM practices with varying degrees. 
Table 1. Traditional and Modern HRM Practices Scores

\begin{tabular}{|c|c|c|c|c|c|}
\hline \multicolumn{3}{|c|}{ Traditional HRM Practices (Mean Values) } & \multicolumn{3}{|c|}{ Modern HRM Practices (Mean Values) } \\
\hline HRM Practice & SOEs & PEs & HRM Practice & SOEs & PEs \\
\hline Detailed Selection & 3.98 & 2.12 & $\begin{array}{l}\text { Employee referrals based } \\
\text { selection }\end{array}$ & 1.02 & 2.88 \\
\hline Training-Technical Skills & 4.03 & 1.98 & Multiple Skill Training & 0.93 & 3.02 \\
\hline Individual work & 3.67 & 1.96 & Teamwork & 1.33 & 3.04 \\
\hline $\begin{array}{c}\text { Employee participation in decision } \\
\text { implementation }\end{array}$ & 4.22 & 2.02 & $\begin{array}{c}\text { Employee participation in } \\
\text { decision-making }\end{array}$ & 0.78 & 2.98 \\
\hline Designation-based compensation & 4.96 & 2.14 & $\begin{array}{l}\text { Performance-based } \\
\text { compensation }\end{array}$ & 0.04 & 2.86 \\
\hline Performance Appraisal & 3.96 & 1.84 & Performance Development & 1.04 & 3.16 \\
\hline Money-based motivation & 4.21 & 2.64 & Non-money motivation & 0.79 & 2.36 \\
\hline
\end{tabular}

\section{Descriptive Data Analysis}

Descriptive analysis provides simple summaries about the sample and about the observations that have been made. The sample data used to analyse the minimum and maximum values of the respondents. And the mean values with associated standard deviation also computed to explain the central tendency of the sample data about employee performance and HRM practices of both SOEs and PEs.

Table 2 presents Mean and Standard Deviation (SD) values of HRM practices and performance of employees in SOEs.

Table 2. Mean and SD values of HRM Practices and Performance of Employees in SOEs

\begin{tabular}{|c|c|c|c|c|}
\hline $\begin{array}{c}\text { Major HR } \\
\text { Practices }\end{array}$ & Min & Max & Mean & SD \\
\hline Selection & 2.00 & 4.00 & 2.75 & 0.92 \\
\hline Training & 1.00 & 3.00 & 2.62 & 0.72 \\
\hline Teamwork & 2.00 & 3.00 & 2.55 & 0.64 \\
\hline $\begin{array}{c}\text { Employee } \\
\text { participation }\end{array}$ & 1.00 & 3.00 & 2.00 & 0.93 \\
\hline $\begin{array}{c}\text { Compensation } \\
\text { Performance } \\
\text { Appraisal \& } \\
\text { Development }\end{array}$ & 1.00 & 4.00 & 2.65 & 0.68 \\
\hline $\begin{array}{c}\text { Motivation } \\
\text { Performance } \\
\text { Level }\end{array}$ & 2.00 & 3.00 & 1.70 & 1.08 \\
\hline
\end{tabular}

Table 2 depicts the score of descriptive data analysis of the each of the HRM practices of SOEs. The mean score of the performance appraisal indicated the lowest score of 1.70 out of 5.00. The mean score indicated that performance appraisal practice had the least influence on employees' performance. The Standard Deviation (variability) score of this measure is 1.08 that indicates that the level of perceived influence of this practice varied widely among employees. The mean scores of employee participation and motivation were 2.00 and 2.26 respectively. Their SD scores were 0.93 and 0.86 . These scores indicate that the perceived influence of these HRM practices on employee preference is low and varied significantly, but better than that of performance appraisal practice. The mean scores of teamwork, training, compensation and selection practices indicate that the influence of these practices is better than that of all other practices, even though the influence is just above 2.50 out of 5.00. Similarly SD scores of these practices indicate that the variability is less compared to that of all other practices. In addition, it is evident from this table that no respondent from SOEs indicated highest influence of these HRM practices on employee performance.

Employee performance level score indicated that employees' performance is just 2.25 out of their maximum abilities. It is observed from intersectional analysis from Table 1 and Table 2 that the traditional HRM practices could result in employees' performance up to only $45 \%$ (2.25 out of 5.00) of employees' abilities in SOEs.

Table 3 presents mean and Standard Deviation (SD) values of HRM practices and performance of employees in PEs.

Table 3. Mean and SD Values of HRM Practices and Performance of Employees in PEs

\begin{tabular}{|c|c|c|c|c|}
\hline Major HR Practices & Min & Max & Mean & SD \\
\hline Selection & 3.00 & 5.00 & 3.92 & 0.45 \\
\hline Training & 2.00 & 4.00 & 3.66 & 0.37 \\
\hline Teamwork & 3.00 & 4.00 & 3.88 & 0.38 \\
\hline Employee participation & 3.00 & 4.00 & 3.76 & 0.48 \\
\hline Compensation & 2.00 & 4.00 & 2.85 & 0.52 \\
\hline $\begin{array}{c}\text { Performance Appraisal \& } \\
\text { Development }\end{array}$ & 3.00 & 4.00 & 3.65 & 0.38 \\
\hline Motivation & 3.00 & 5.00 & 3.98 & 0.45 \\
\hline Performance Level & 2.00 & 4.00 & 3.72 & 0.45 \\
\hline
\end{tabular}

Table 3 depicts the score of descriptive data analysis of the each of the selected HRM practices of PEs. The mean score of the compensation indicated the low score of 2.85 out of 5.00 with a SD score of 0.52 . Mean scores of all other factors is above 3.00 out of 5.00. Selection and motivation practices scores were high indicating the management's emphasis on these practices. In addition performance score is above moderate level of 3.00 . SD scores indicate that the variation of responses was also low. In summary, mean scores and SD values indicate that influence of HRM practices on performance is significant. 
Employee performance level score indicated that employees' performance is 3.72 out of their maximum abilities. It is observed from intersectional analysis fromTable- 1 and Table- 3 that the traditional HRM practices could result in employees performance up to only $45 \%(2.25$ out of 5.00) of employees' abilities in SOEs, whilst the modern HRM practices resulted in employee performance up to $74.4 \%$ of their abilities.

The descriptive data analysis reveals that HRM practices in PEs is more effective than that of SOEs mostly due to the fact that PEs used modern HRM practices whilst SOEs used traditional HRM practices.

Further evaluation of these results was done to ascertain the association between the HRM practices and level of performance of employees in SOEs and PEs with correlation analysis.

\section{Correlation Analysis}

The correlation analysis is performed to analyse the association between the dependent and independent variables of HRM practices and employees performance. Table 4 presents correlation between the HRM practices and performance in SOEs.
This results showed a positive correlation between all variables measuring HRM practices and performance level.. Intersectional analysis of tables 1 and 4 indicates that practice of traditional HRM practices tend to result in low performance in view of moderate correlation between HRM practices and performance level in most of the HRM practices in SOEs.

Table 5 presents correlation among HRM practices and performance in PEs.

Table 5 indicates that correlation between each of the HRM practices and performance level is positive and significant, too high in almost all HRM practices in PEs. However, the correlation between compensation and performance level is low compared to that of other HRM practices. Intersectional analysis of Table 1 and Table 5 indicates that practice of modern HRM practices tend to result in high performance level in view of moderate to high correlation between HRM practices and performance level in PEs.

Regression analysis was used to bold a model of the relationship between the dependent and independent variables.

Table 4. Correlation among the HRM Practices and Employee Performance in SOEs

\begin{tabular}{|c|c|c|c|c|c|c|c|c|c|}
\hline & & V1 & V2 & V3 & V4 & V5 & V6 & V7 & V8 \\
\hline V1 & Selection & 1.00 & & & & & & & \\
\hline V2 & Training & 0.65 & 1.00 & & & & & & \\
\hline V3 & Teamwork & 0.55 & 0.50 & 1.00 & & & & & \\
\hline V4 & Employee participation & 0.65 & 0.55 & 0.55 & 1.00 & & & & \\
\hline V5 & Compensation & $0.68^{*}$ & $0.70^{*}$ & 0.58 & 0.57 & 1.00 & & & \\
\hline V6 & Performance Appraisal \& Development & 0.45 & 0.45 & 0.49 & 0.58 & 0.64 & 1.00 & & \\
\hline V7 & Motivation & 0.65 & 0.55 & 0.40 & 0.50 & 0.68 & 0.56 & 1.00 & \\
\hline V8 & Performance Level & 0.58 & 0.65 & $0.66^{*}$ & 0.55 & $0.65^{*}$ & 0.63 & $0.70^{*}$ & 1.00 \\
\hline
\end{tabular}

*Correlation significant at level 5\%

Table 5. Correlation among the HRM Practices and Employee Performance in PEs

\begin{tabular}{|c|c|c|c|c|c|c|c|c|c|}
\hline & & V1 & V2 & V3 & V4 & V5 & V6 & V7 & V8 \\
\hline V1 & Selection & 1.00 & & & & & & & \\
\hline V2 & Training & 0.63 & 1.00 & & & & & & \\
\hline V3 & Teamwork & 0.65 & 0.60 & 1.00 & & & & & \\
\hline V4 & Employee participation & 0.58 & 0.65 & 0.60 & 1.00 & & & & \\
\hline V5 & Compensation & 0.65 & 0.70 & 0.72 & 0.55 & 1.00 & & & \\
\hline V6 & Performance appraisal & 0.55 & 0.72 & 0.68 & 0.58 & 0.67 & 1.00 & & \\
\hline V7 & Motivation & 0.58 & 0.68 & 0.60 & 0.68 & 0.69 & 0.64 & 1.00 & \\
\hline V8 & Performance & 0.78 & 0.76 & 0.81 & 0.76 & 0.62 & 0.69 & 0.73 & 1.00 \\
\hline
\end{tabular}




\section{Regression Analysis}

Multiple Regression Model (MLR) has been developed in order to analyse the effects of HRM practices on employee performance by using the regression analysis with MS excel software.

Employee Performance is taken as dependent variable and HRM practice variables are taken as independent or explanatory variable.

Employee Performance

Selection

Training

Teamwork

Employee participation

Compensation

Performance appraisal

Motivation

Ep - Dependent variable

Se - Independent variable

$\mathrm{Tr}$ - Independent variable

Tw - Independent variable

Em - Independent variable

Co - Independent variable

$\mathrm{Pa}$ - Independent variable

Mo - Independent variable

The regression Model is represented as:

$\mathrm{Ep}_{\mathrm{it}}=\beta_{0}+\beta_{1} \mathrm{Se}+\beta_{2} \mathrm{Tr}+\beta_{3} \mathrm{Tw}+\beta_{4} \mathrm{Em}+\beta_{5} \mathrm{Co}+\beta_{6} \mathrm{~Pa}+\beta_{7} \mathrm{Mo}$

In the above model $\beta_{0}$ is constant and $\beta_{1}-\beta_{7}$ are regression coefficient of the independent variables while $e_{i t}$ is the residual error of the regression.

Table 6 depicts the Output of multiple regression analysis of dependent and independent variables.

Table 6. Output of Multiple Regression Analysis of Dependent and Independent Variables

\begin{tabular}{|c|c|c|c|}
\hline & $\begin{array}{c}\text { Variables } \\
\text { (Predictors) }\end{array}$ & $\begin{array}{c}\text { Coefficient of } \\
\text { variable }(\beta) \\
\end{array}$ & ' $\mathrm{P}$ ' values \\
\hline & Constant & 0.45 & 0.005 \\
\hline Se & Selection & 0.75 & 0.025 \\
\hline $\mathbf{T r}$ & Training & 0.68 & 0.015 \\
\hline $\mathbf{T w}$ & Teamwork & 0.71 & 0.025 \\
\hline $\mathbf{E m}$ & $\begin{array}{l}\text { Employee } \\
\text { participation }\end{array}$ & 0.74 & 0.012 \\
\hline Co & Compensation & 0.68 & 0.024 \\
\hline Pe & $\begin{array}{l}\text { Performance } \\
\text { appraisal \& } \\
\text { development }\end{array}$ & -0.45 & 0.032 \\
\hline Mo & Motivation & 0.68 & 0.023 \\
\hline & $\mathbf{R}$ squire value & 0.768 & \\
\hline & F test & 16.85 & \\
\hline
\end{tabular}

Table 6 shows the output of the regression analyses of the dependent and independent variables of the HRM practices of the both sector of SOEs and PEs. Coefficient $(\beta)$ is a predictor of each variables related to the HRM practices. Based on the multiple regression analysis, the regression model of the HRM practices and Employee performance (Ep) as given below

$\mathrm{Ep}=$

$0.45+0.75 \mathrm{Se}+0.68 \mathrm{Tr}+0.71 \mathrm{Tw}+0.74 \mathrm{Em}+0.68 \mathrm{Co}-0.45 \mathrm{Pe}+0.6$ $8 \mathrm{Mo}$
Employee performance (EP) level depends on the set of HRM practices, as per above model 0.45 is constant score of EP is equal to 0.45 where if all other HRM practices scales are zero. The EP regression model, all the coefficient of the HRM practices contributes positive correlations on the employee performance. Only the performance appraisal practice coefficient of -0.45 is express negative correlation on the employee performance, which needs further investigations. $\mathrm{P}$ values of each variable are indicates the existence of significance relationship between the Employee performance and set of HRM practices in 5\% $(0.05)$ significance level.

The $\mathrm{R}$ square $\left(\mathrm{R}^{2}\right)$ valued highlight that $76.8 \%$ variability in the employee performance was influenced by HRM practices of traditional or modern approach of HRM practice.

The testing for the significance of the independent variables is based on regression model. The F- test value is 16.85 and P-values less than 5\% for the data variables indicates these very well fit of regression model. In other words, many of the HRM practices significantly connected with employee performance.

\section{Conclusions}

Employee performance is the outcome of the influence of various factors. Important among these are the human resource management practices. Globalisation and information technology resulted in the emergence of modern practices of HRM that are different in approach from the erstwhile HRM practices. The erstwhile HRM practices are termed as traditional HRM practices. Some organisations mostly SOEs use traditional HRM practices while others and mostly PEs in this study use modern HRM practices.

Data analysis indicates that employees' performance in SOEs is $45 \%$ of their abilities while it is $74.4 \%$ in case of PEs. Further they indicate that moderate correlation exists between HRM practices and performance level in SOEs and moderate to high correlation exists between HRM practices and performance level in PEs. The $R$ square $\left(R^{2}\right)$ valued highlight that $76.8 \%$ variability in the employee performance can be explained by HRM practices. The F- test value is 16.85 and $\mathrm{P}$-values is less than 5\% significant level for the data variables indicates these very well fit of regression model.

Results of the study indicate that many of the traditional HRM practices resulted in the low employee performance in SOEs whilst modern HRM practices resulted in high employee performance in PEs.

SOEs mostly followed traditional HRM practices and PEs followed modern HRM practise mostly due to their organisational structures.

It is therefore suggested that SOEs may take the advantage of high employee performance by restructuring their organisations that allow them to follow modern HRM practices. 


\section{REFERENCES}

[1] Mildred Golden Pryor, J. Chris White, and Dr. Leslie A. Toombs - Strategic Quality Management, A Strategic Systems Approach to Continuous Improvement. New Guinea: an analytical evaluation", A Global Development Network and AusAID study, Monograph, 2008.

[2] Mst. Momena Akhter, Md. Nur-E-Alam Siddique and Asraful Alam , "HRM Practices and its Impact on Employee Performance: A Study of the Cement Industry in Bangladesh", Global Disclosure of Economics and Business, Volume 2, No 2 (2013).

[3] Paauwe J, Guest DE, Wright P. HRM and Performance: Achievements and Challenges. UK: Wiley Press; 2013.

[4] Yasir Tanveer, Muhammad Zeeshan Shaukat, Sheraz Ahmad Alvi and Aysha Munir, "The Way Human Resource Management (HRM) Practices Effect Employees Performance: A Case of Textile Sector", International Journal of Economics and Management Sciences, Vol.1, No. 4, pp.112-117,2011.

[5] Zaini Abdullah, Nilufar Ahsan and Syed Shah Alam, " The Effects of Human Resource Management Practices on Business Performance among Private Companies in Malaysia", International Journal of Business and Management, Vol.4., No.6, June, pp.65-72, 2009.

[6] Weinberg DB, Avgar AC, Cooney-Miner NM, Sugrue D. The importance of a high-performance work environment in

hospitals. Health Serv Res. 2013;48(1):319-332.

[7] Baker, George, Gibbson Robert and Murphy Kevin J, "Subjective Performance Measures in Optimal Incentive Contracts", Quarterly Journal of Economics, November,108(8), pp.1125-56, 1994.

[8] Carmichael. H. Lorne and MacLeod, W. Bentley, "Multiskilling, Technical Change and the Japanese Firm", The Economic Journal, 103 (416) pp.142-160,1993.

[9] Givan RK, Avgar A, Liu M. Having your cake and eating it too? The relationship between HR and organizational performance in healthcare. Adv Ind Lab. 2010;17:31-67.

[10] Weitzman, Martin L., and Douglas L. Kruse," Efficient Incentive Contracts and "Profit Sharing and Productivity". In Paying for Productivity: A Look at the Evidence, ed. Alan S. Blinder, the Brookings Institution, Washington, D.C., pp. 95-139,2004.

[11] Kavanamur, D., Okole, H with Manning, M. and Levantis, T., "Understanding reforms in Papua New Guinea: an analytical evaluation", A Global Development Network and AusAID study, Monograph, 2004.

[12] Imbun, B. Y., "Human Resource Management in PNG Mining: Evidences from Porgera", in Imbun, B. Y. and McGavin, P. A., (eds) Mining in Papua New Guinea, University of Papua New Guinea Press, Port Moresby, 96-112,2001.

[13] Subba Rao, Pulapa, Manohar, P. And Mellam Albert, "Leadership Styles and their Contribution to Performance and Satisfaction of Leaders and Followers in State Owned and Private Enterprises in Papua New Guinea”, Delhi Business Review, vol.9, no.1,2008. 